\title{
Endometriosis Presenting As Bartholin Gland Cyst
}

\section{Bartolin Kisti Olarak Prezente olan Endometriosis}

\section{Ali Yavuzcan', Hüseyin Cengiz², Gazi Yıldız', Aslı Demir Şam³ , Pınar Yıldız', Bilal Çelikbaş ${ }^{4}$}

${ }^{1}$ Department Of Obstetrics And Gynecology, Bucak State Hospital, Burdur, Turkey

${ }^{2}$ Department Of Obstetrics And Gynecology, Bakırköy Dr. Sadi Konuk Teaching And Research Hospital, Istanbul, Turkey.

${ }^{3}$ Department of Pathology, Bucak State Hospital, Burdur, Turkey.

${ }^{4}$ Department of Surgery, Bucak State Hospital, Burdur, Turkey.

Yazışma Adresi / Corresponding to:

Dr. Ali Yavuzcan. 260. Sokak $72 / 1035100$ İzmir - Türkiye

Tel: 05053185878 Mail: draliyavuzcan@yahoo.com

We presented an extremely rare form of endometriosis presenting as a Bartholin gland cyst. A 39-year-old woman, gravida 2 para 2, experienced an enlarging mass of the left labium majus. Cystectomy was performed and histopathologic examination confirmed the presence of endometriosis. One year after operation, the patient is symptom free with no signs of cyst recurrence. Bartholin gland endometriosis should be kept in mind when women of reproductive age have a diagnosis of Bartholin cyst.

Keywords: bartholin gland, endometriosis, vulva.

Bu raporda endometriozisin son derece nadir görülen bir formu olan Bartholin bezinde prezente olan hali sunulmuștur. 39 yaşında, gravidası 2 paritesi 2 olan hasta sol labium majusta bir şişlik ile başvurmuştur. Hastaya kistektomi yapılmıştır ve histopatolojik inceleme ile endometriozis varlığı tespit edilmiştir. Operasyon sonrasındaki bir yıllık takiplerde hastada nüks gelişmemiştir ve herhangi bir semptom saptanmamıştır. Üreme çağındaki kadınlarda Bartholin bezi kisti tanısı konulurken Bartholin bezi endometriozisi ayırıcı tanıda akılda tutulmalıdır.

Anahtar Kelimeler: bartolin bezi ,endometriozis, vulva. 


\section{Introduction}

Endometriosis is a common gynecologic disorder, that occurs in approximately $1 \%$ to $7 \%$ of women in the United States 1. Endometriosis is characterized by the growth of endometrial glands and stroma outside the endometrium. Implants are most commonly found in the pelvis but can occur in many other sites. Vulvar involvement of endometriosis is a fairly rare phenomenon. Matseoane et al. reported the first case of endometriosis in Bartholin gland ${ }^{2}$. We presented a case of endometriosis presenting within the Bartholin gland that is an extremely rare phenomenon.

\section{Case Report}

A 39-year-old woman, gravida 2 para 2, had been experiencing vulvar enlarging mass of the left labium majus over a period of 10 years. The mass was palpable since the delivery of her second baby. The patient gave birth vaginally without an episiotomy. The patient was admitted to clinic because of menstrual disorder. She had no history or symptoms to suggest the presence of endometriosis. On examination the mass was nodular and firm; it was $4 \mathrm{~cm}$ in length and 3,5 cm in width arising from subcutaneous tissue in the left labium majus on the posterolateral aspect of the vestibule (Figure 1). Her vaginal examination revealed no abnormalities except for a minimal brownish discharge coming from the uterus. The uterus and ovaries were unrestricted. The haemoglobin level was $8.5 \mathrm{~g} / \mathrm{dl}$, the leukocyte count $4000 / \mathrm{mm} 3$ and the platelet count $105000 / \mathrm{mL}$. Her hormonal profile was within normal range. The uterus and both ovaries were normal at transvaginal ultrasonographic examination with a normal endometrial lining thickness of $11 \mathrm{~mm}$. The endometrial biopsy was performed in a routine fashion due to presence of metrorrhagia over last three months. Endometrial biopsy demonstrated proliferative endometrium without evidence of histopathologic abnormalities.

We performed cystectomy for Bartholin cyst under general anesthesia. During the operation, cyst wall was ruptured and a chocolate-colored content poured into operation field (Figure 1). Then the cystectomy had been performed.

The histopathologic examination confirmed the presence of endometriosis. Superficial erosion and fibrotic granulation of tissue were seen (Figure 2). Associated areas of fibrosis as well as small aggregated of hemosiderin were also commonly observed (Figure 3). The endometriotic foci were located in the Bartholin's gland wall . Endometriotic foci were not accompanied by an inflammatory mass, neoplasm or any other pathology.The patient was not infertile. She did not have dismenorea, disparonia or any other gynecological disorders except menstrual disorder. We did not perform an operation to rule out the presence of a possible intraabdominal disesase. Tissue diagnosis and staging of intraabdominal endometriosis could not be confirmed. The goal of treatment was only to control the menstrual cycle. The patient was discharged on the second postoperative day with $10 \mathrm{mg}$ norethindrone acetate daily use for three months. One year after operation, the patient is symptom free with no signs of recurrence.

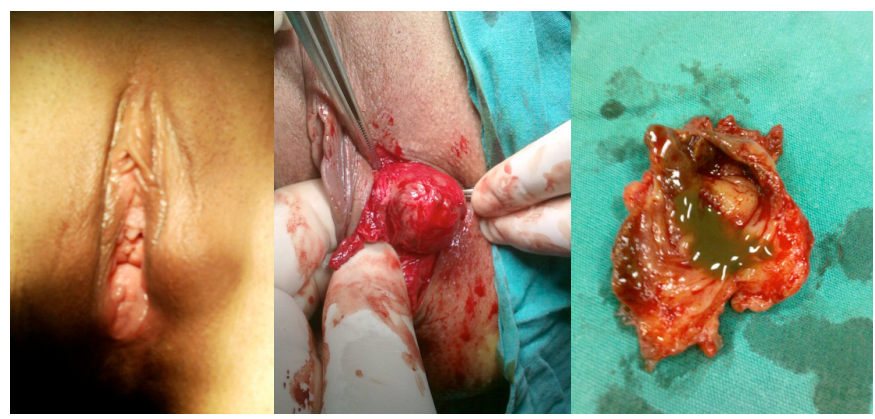

Figure 1. Peroperative views of vulvar endometrioma.

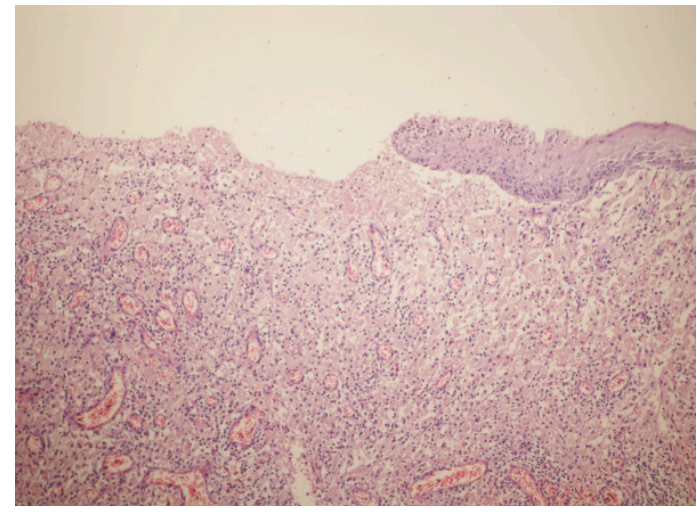

Figure 2. Stroma, fibrotic granulation tissue in Bartholin gland, $\mathrm{H} \& \mathrm{E}$, original magnification $\times 10$. 


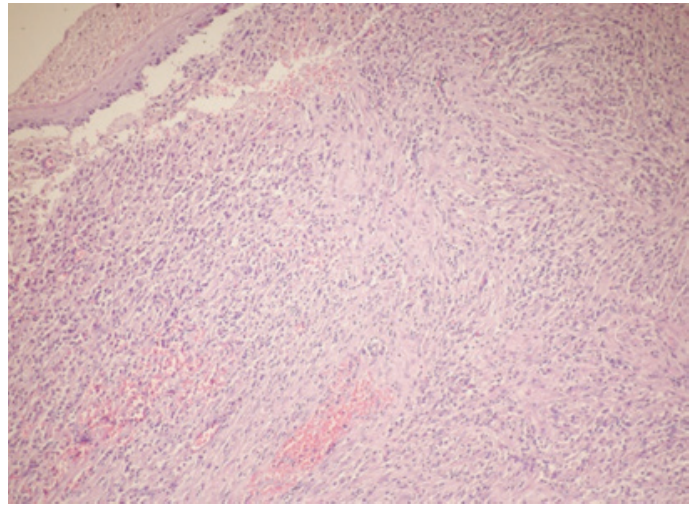

Figure 3. Hemosiderin loaded macrophages in the squamous epithelium lined Bartholin gland, H\&E, original magnification $x 20$.

\section{Discussion}

Differential diagnosis of cystic and solid vulvar lesions is a complex problem for physcians. The lesion can be cystic or solid. Also it can be located at labia majora (usually), vestibule, between labium majus and labia minora and only at labia minora, Bartholin's duct cyst, epidermal inclusion cyst, mucous cyst of the vestibule, hidradenoma papilliferum, cyst of the canal of Nuck and Skene's duct cyst are most common cystic lesions. The most common solid lesions are fibroma, lipoma, leiomyoma, neurofibroma, angiokeratoma and squamous cell carcinoma (3). Extrapelvic endometriosis, though uncommon, can occur in subcutaneous tissues of surgical scars, or in the surrounding areas, following obstetric and gynaecological procedures (4). Endometrioma formed within the gland of Bartholin is an extremely rare phenomenon.

The ectopic endometrium usually results from transplantation of viable endometrial tissue, which is shed in retrograde manner through the fallopian tube at the time of menstruation (Sampson's theory) (5). Endometriosis may be accepted as an auto-transplant, in which normal endometrial tissue is adhered to an ectopic location in the organism. However, this theory fails to explain the presence of endometriosis in the areas outside the peritoneal cavity, as the lungs, skin, lymph nodes, breasts (6-7). The origin of endometriosis in extra abdominal pelvic sites is not fully understood yet. There are only a few reported cases about endometioma mimicking Bartholin cyst . One of these cases was bilateral endometrioma of Bartholin glands $2,8-10$.
Direct extension of endometriosis along the round ligament from preexisting pelvic endometriosis can explain endometriosis of the labium majus. An isolated focus of endometriosis in the Bartholin gland can, theoretically, be the result of ceolomic metaplasia, lymphatic and/or vascular spread. Hormonal stimulation can result in the growth of endometrial fragments that have reached the Bartholin gland via menstrual discharge (8). The etiopathogenetic mechanism of Bartholin gland endometriosis would be related to iatrogenic transplantation of endometrium during delivery or gynecological surgery. Vulvar endometriosis in other previous cases were probably the result of implantation of endometrial tissue in open accidental vulvar trauma; during sexuel intercourse or during endometrial biopsy performed. Buda et al. clinically confirmed this iatrogenic pathogenesis after laparoscopic surgery ${ }^{11}$. On the other hand; our patient did not have a history of any gynecological invasive process. She gave birth vaginally without an episiotomy. But she told that the mass was occured just after her second delivery.

The treatment of endometriosis disease and cyctic lesions of endometriosis at vulva should be planned according to the patient's age, her desire for future pregnancies, the severity of the clinical symptoms, the location of the lesion, and the involvement of other organs. Management alternatives are medical (hormonal), surgical, or expectant ${ }^{12}$. We performed cystectomy. A diagnostic laparoscopy was not performed during Bartholin cystectomy operation. She was given $10 \mathrm{mg}$ norethindrone acetate per day due the treatment of dysfunctional uterine bleeding for three months. No recurrence was determined in the patient until now. In patients with fertility problems, laparoscopy could be performed during or after the cystectomy operation to find out the evidence of intraabdominal endometriosis, correct pelvic anatomy and ensure fertility. It is debatable to perform laparoscopy in multiparous women operated with another gynecological reason. In patients with a Bartholin cyst having variability in size during menstrual cycle and associated with infertilitylother common symptoms of endometriosis; it is important to be suspicious about Bartholin gland endometrioma.

\section{Conflict of interest}

None. 


\section{References}

1. Barbieri RL. Etiology and epidemiology of endometriosis. American Journal of Obstetrics and Gynecology 1990;162: 565-7.

2. Matseoane S, Harris T, Moscowitz E. Isolated endometriosis in a Bartholin gland. N Y State J Med 1987; 87:575-6.

3. Omole F, Simmons BJ, Hacker Y. Management of Bartholin's duct cyst and gland abscess. Am Fam Physician 2003; 68:135-40.

4. Pikoulis E, Karavokiros J, Veltsista K, Diamantis T, Griniatsos J, Basios N, Avgerinos $E$, Marinos $G$, Kaliakmanis V. Abdominal scar endometriosis after caesarean section: report of five cases. West Indian Med J 2011 ;60:351-3.

5. Sampson JA. The development of the implantation theory for the origin of peritoneal endometriosis. Am J Obstet Gynecol 1940; 40:549.

6. Bulun SE, Endometriosis, N Engl J Med 2009; 360:268-9.

7. Cristescu C, Velişcu A, Marinescu B, P[traşcu A, Traşc $\square$ ET, Pop OT.
Endometriosis - clinical approach based on histological findings. Rom J Morphol Embryol 2013;54:91-7.

8. Gocmen A, Inaloz HS, Sari I, Inaloz SS. Endometriosis in the Bartholin gland. Eur J Obstet Gynecol Reprod Biol 2004; 114:110-1.

9. Su HY, Chen WH, Chen $\mathrm{CH}$. Extra-pelvic endometriosis presenting as a vulvar mass in a teenage girl. Int J Gynecol Obstet 2004; 87:252-3.

10. Aydin Y, Atis A, Polat N. Bilateral endometrioma of Bartholin glands accompanying ovarian endometrioma. J Obstet Gynaecol 2011; 31:187-9.

11. Buda A, Ferrari L, Marra C, Passoni P, Perego P, Milani R. Vulvar endometriosis in surgical scar after excision of the Bartholin gland: report of a case. Arch Gynecol Obstet 2008; 277:255-6.

12. Woodward PJ, Sohaey R, Mezzetti TP Jr. Endometriosis: radiologicpathologic correlation. Radiographics 2001; 21:193-216. 